\title{
Information Technology and the Ethics of Globalization
}

\author{
Robert A. Schultz \\ Woodbury University, Burbank, CA, USA
}

Bobschultz Ivt@yahoo.com

\begin{abstract}
Globalization, the coalescence of the economies and cultures of this planet, has raised new ethical issues. Information Technology (IT) is an enabler of globalization, but IT also produces new ethical problems. There is already a substantial literature in philosophy and political theory on globalized ethics, but not much on IT's special impact on globalized ethics.

This paper is a sketch of the main argument of a book I am writing on this topic. I first give examples of to show how these IT-enabled global ethical problems come about. Then, in the second and third parts of the paper I briefly summarize the main theories of globalized ethics and show their inadequacies in dealing with IT-enabled global ethical problems. In the final part, I sketch a social contract approach which can begin to deal with these IT-enabled global ethical problems. This approach derives from the work of John Rawls (1999a) on justice.
\end{abstract}

Keywords: Information Technology, Globalization, Ethics, Justice, Social Contract, Rawls, Utilitarianism, Global Institutions

\section{Introduction}

Globalization, the coalescence of the economies and cultures of this planet, has definitely been enabled by Information Technology (IT). Globalization, in altering previous economic and social structures, has raised new ethical issues of concern to managers, IT professionals, and the rest of us. But IT is much more, I think, than a mere enabler of globalization. Within globalization, IT produces new ethical problems all by itself. There is already a substantial literature in philosophy and political theory on globalized ethics, but not much on IT's special impact on globalized ethics.

This topic would require a book for an adequate treatment. In fact, I am in the process of writing such a book, titled Information Technology and the Ethics of Globalization: Transnational Issues and Implications, to be published by IGI Press in 2009. So what appears here is a sketch of the main argument of that book. Also, the methodology used in the book can again only be sketched

Material published as part of this publication, either on-line or in print, is copyrighted by the Informing Science Institute. Permission to make digital or paper copy of part or all of these works for personal or classroom use is granted without fee provided that the copies are not made or distributed for profit or commercial advantage AND that copies 1) bear this notice in full and 2) give the full citation on the first page. It is permissible to abstract these works so long as credit is given. To copy in all other cases or to republish or to post on a server or to redistribute to lists requires specific permission and payment of a fee. Contact Publisher@InformingScience.org to request redistribution permission. here. It is the method of reflective equilibrium. A good brief account can be found in Daniels 2003. Roughly, particular ethical judgments and theory are allowed to force alterations in each other. It is an especially good method to use for new ethical problems. In this sketch, for reasons of space I simply apply the method without showing exactly how. 
In the first part of this paper, I will give examples of how these IT-enabled global ethical problems come about. Then, in the second and third parts of the paper I will briefly summarize the main theories of globalized ethics and show their inadequacies in dealing with IT-enabled global ethical problems. In general, authors of these theories do not sufficiently appreciate the changes IT makes to underlying social and economic structures.

In the final part, I will sketch a social contract approach which can begin to deal with these ITenabled global ethical problems. This contractarian approach derives from the work of John Rawls on domestic and international justice. The essence of this approach is that people in societies live under principles which they themselves could have chosen. Its political and ethical attractiveness is that coercive social and governmental commands are grounded in free agreement rather than in arbitrary force. Classic social contract theory was developed by the philosophers Hobbes (1651), Locke (1690), and Rousseau (1762). These theories were the basis for American and French democracies.

\section{Examples of IT-Enabled Ethical Problems}

I will discuss two examples: The World Bank and its IT development, and Yahoo in China. I chose these examples to show that problems of IT-enabled globalization are a new kind of ethical problem and require new ethical principles for their solution. Other examples could have been chosen.

\section{IT development at the World Bank}

The Harvard Business School published in 2003 a case study of IT development at the World Bank (McFarlan \& DeLacey, 2003). The IT staff were notably successful in improving the functioning of the World Bank and enabling it to work better toward its stated goals. But the World Bank's stated high ideals of improving life in developing countries are, according to economist Joseph Stiglitz, not realized in practice. Stiglitz, a Nobel prize winner and himself a former Senior Vice President of the Bank, finds that the World Bank actually often makes conditions worse in developing countries. (Stiglitz, 2003, 2007)

The mission of the World Bank is to fight poverty around the world by providing resources, sharing knowledge and enabling public/private partnerships. This is to be accomplished by attracting and maintaining a committed staff with exceptional skills. The World Bank is financed by investors in 184 member countries, primarily through bond purchases. In 2003, the Bank adopted a strategy of global decentralization and facilitating knowledge transfer to developing countries. In the face of numerous challenges, their IT department succeeded in enabling these goals (McFarlan \& DeLacey, 2003).

However, decentralized administration and knowledge transfer do not, in the context of World Bank administration, succeed in improving the lot of those in development countries. The problem, according to responsible commentators such as Joseph Stiglitz, is that the World Bank (together with the International Monetary Fund) attaches conditions to its loans and grants which reflect more the ethics of international banking than that of alleviating poverty. Typically, keeping to agreements to repay loans and privatization of government services are required. During the 2002 Argentina default, enormous increases in debt service on its loans triggered by events in the U.S. and east Asia, together with loss of revenues caused by privatized services moving out of the country, were simply made worse by IMF and World Bank policies (Stiglitz, 2007, pp. 220225). Other problems include loans going to entrenched oligarchies rather than development projects. In general about 50\% of World Bank projects fail (Center for Economic Justice 2004).

There are several layers of ethical considerations to be untangled here. If one accepts Stiglitz's account of the World Bank's failings, then the IT staff at the World Bank has enabled a dimin- 
ished future for many in developing countries. His views are shared by many and there is currently a boycott campaign against buying bonds issued by the World Bank. Participants include municipalities, the college pension organization TIAA/CREF, as well as a number of labor unions. (Boycott support is for financial risk reasons as well as socially conscious reasons).

The ethical situation has parallels to IT development for ethically flawed organizations, for example tobacco manufacturers, or, less controversially, distributors of child pornography. If, for example, an IT professional were to produce a first rate website and back office system for an outfit distributing child pornography, there would not be much question about the ethical status of his activity. The activity of the organization is highly unethical, so it is not ethical to aid and abet its implementation. Tobacco seems more of an intermediate case. Certainly tobacco manufacturers are operating legally, so ethically it is up to the IT professional whether he wants to work for this sort of company. But the difference in the case of the World Bank is that it is not immediately clear what ethical standards are appropriate for a globalized organization. Ought the IT professionals who did such a good job for the World Bank consider the Bank's impact on developing countries? Or do ethical standards of international banking take precedence? What ethical conclusion should they draw?

When is "I only work here. I'm only following orders" an acceptable ethical defense? Clearly it matters how directly implicated people are in ethically questionable activities. The IT professional enabling child pornography distribution clearly cannot say "I only work here" to establish that he is acting ethically. We expect him to recognize that the activity he is enabling is both illegal and unethical. The IT professional enabling the sale of tobacco can say "I only work here." Producing and developing tobacco products is legal. It is another question whether distributing a product which tends to kill people in large numbers should be legal. But so long as it is legal, it is a matter of personal ethical preference whether or not to aid and abet the production and distribution of tobacco. It would be ethically better not to aid and abet the tobacco industry but it is not ethically required.

However, why wasn't Adolf Eichmann, who was in charge of administering the Holocaust, able to use "I only work here" as a defense? He tried, unsuccessfully (Arendt 1965). And as in the tobacco example, he was following German laws implementing the "final solution". Yet a street sweeper in Nazi Germany, although he contributed to keeping Germany running and thus helped to enable the Holocaust, could legitimately say "I only work here." What's the difference? If it is ethical to aid a tobacco company in its operations, it can only be because we regard the legality of the tobacco company as at least ethically neutral. We do not regard laws mandating genocide as ethically neutral.

So is the situation with the IT staff at the World Bank more like the situation at the child pornography website or at the tobacco company? Because of globalization, there is not an immediate answer. The World Bank is a globalized institution and so its legality is not determined by the laws of any one state. Further, the ethical status of its operations is not determined by the ethical standards of any one nation. And, as we shall see in section two of this paper, there are several different choices for transnational ethical standards. My personal intuition would be that the World Bank case is ethically the same as the tobacco company case, but to support this intuition requires choice of specific transnational ethical standards.

\section{Yahoo in China}

On or around 2002, Yahoo provided the Chinese government with information about two prodemocracy journalists who were subsequently jailed and apparently tortured. The journalists successfully sued Yahoo. Yahoo initially claimed that it was merely complying with Chinese law (Elias, 2007). The obvious ethical issue is whether Yahoo should do this, whether the law of a 
country not recognizing basic human rights should be followed. The background question is whose law, if any, should be followed by a transnational company? Again, the fact that this is an IT company makes the question a lot harder to answer. With outsourced manufacturing, the choice would be the country where operations take place. With Yahoo, it is not so clear, although Yahoo itself seemingly followed some such principle by selling its Chinese e-mail operation to a Chinese company.

At Yahoo's 2007 annual meetings, Yahoo shareholders voted overwhelmingly against a proposal for Yahoo to reject censorship ("Yahoo's China Policy Rejected", 2007). Obviously Yahoo, as a corporation, is bound by the vote of its shareholders. But ethically do the shareholders of transnational corporations have the last word? What IT has produced in the case of Yahoo and other Internet communications companies are ethically globalized companies, companies whose ethical problems cannot be solved by parceling them out among different nations.

Similarly, the World Bank is an ethically globalized institution, at least in its objectives. Its objectives cannot be understood when parceled out amongst different nations. In fact, it remains ethically globalized even if, as its critics charge, it does not live up to its stated objectives of improving the lives of those in developing countries. For critics claim instead that the World Bank is serving the interests of transnational corporations!

Obviously cases of this kind require us to appeal to some sort of transnational code of ethics. In the next section, we will examine the possibilities. But we will see that for the most part theories of transnational ethics proceed by parceling out ethical problems between states and therefore are not helpful in dealing with ethical problems of ethically globalized institutions, all of which would not exist were it not for IT.

\section{Globalized Ethics}

Ethical principles are first and foremost principles for individuals governing individual behavior. Although for the Greeks, ethics was about character, ethics for us is primarily about right or wrong actions. The Greek word for ethics, ethike, actually means character. Along with the rightness and wrongness of actions, considerations of value belong to ethics. Indeed, a very plausible theory of right action is that the right thing to do is what produces the greatest good for the greatest number. This theory is called utilitarianism (Mill, 1863).

The other important ethical consideration is justice. People, say the employees of a firm or the citizens of a state, can do the right thing and yet keep in motion institutions of great evil. Thus the ethics of institutions - or justice - needs to be assessed as well. In this paper I will use the social contract or contractarian theory of justice of John Rawls, because it grounds justice in the free decision of individuals in a society. So, what principles of justice would be chosen by individuals to govern them? Rule utilitarianism is a plausible candidate: Act on the set of rules likely to produce the greatest amount of good for the greatest number. But what if in such a society you end up as a slave? Parties to a social contract would instead insist that each individual has basic liberties which are not to be compromised or traded off for other benefits. This is Rawls' contractarian first principle of justice, Greatest Equal Liberty: Society is to be arranged so that all members have the greatest equal liberty possible for all. Besides the basic freedoms such as freedom of speech, assembly, religion, and so on, it includes equality of opportunity. Thus society's rules are not biased against anyone in it and allow all to pursue their interests and realize their abilities (Rawls, 1999a).

Rawls' second principle of justice is the Difference Principle: Economic inequalities in society are justified insofar as they make members of the least advantaged social class, better off than if there were no inequality. "Better off" is to be measured against enabling values affected by the social structure reflecting an individual's life prospects. Rawls cites authority, income, and wealth 
as those enabling values (Rawls 1999a, p.78). The social contract basis for the Difference Principle is straightforward: If you are entering a society with no knowledge of your specific place in that society, the Difference Principle guarantees that you will be no worse off than you need be to keep the society functioning.

These principles of justice apply within a society whose members share cooperative benefits and burdens. These days, they are referred to as principles of domestic justice. But what about international or global justice?

There are three basic possibilities for international or global justice: The first two are: Realism, which holds that nations can be just internally (or domestically), but the only ethical principle that applies to and between states is acting in their own self-interest; Society of societies, which holds that societies can be bound by agreements of mutual self-interest. Rawls' Law of Peoples is a contractarian version of this view (1999b). Rawls allows for some ethical constraints - societies refrain from making war on each other and help each other to achieve stability. The third view, cosmopolitanism, holds that all humans are essentially one society, and thus principles of justice applying within societies apply globally. There are utilitarian cosmopolitans such as Peter Singer (2004), who extends utilitarianism within a society to global scope. Contractarian cosmopolitans such as Thomas Pogge (2002) apply Rawls' two principles of justice globally.

I will consider each of these possibilities in turn, noting their suitability for handling ethical issues concerning essentially global institutions. In considering these ethical positions, which apply primarily to institutions, it is worth noting that there is a parallel progression with the development of individual ethics. Individuals accept reasons of self-interest except when following selfinterest conflicts with self-interest, e.g. some sort of mutual advantage. For this to happen, a higher-order principle regarded as overriding self-interest must be mutually adopted. This is the basis for individual ethics. The principle of ethical principles is that when lower-level principles conflict, a higher-order principle resolving the conflict must be given priority (Schultz, 2006, chaps. $1 \& 2$ ).

Thus realism notes that states act in their own interest, and there is no order or principle governing those states other than their own self-interest. Thus states are in what the early contractarian philosopher Thomas Hobbes (1651) called a state of nature with respect to each other. Hobbes describes it as a war of all against all. Clearly considerations of mutual advantage do occur to states, and agreements called treaties occur often in the dealing of states with each other. But realists must hold that when a state's interests are no longer served, the treaty can be ignored. It has to be conceded that the actual behavior of states does closely approximate realism. And there also seems to be no principle acknowledged by states that prevents them from making war at their sole discretion, as recently demonstrated in Vietnam and Iraq. Although ethical principles, unlike legal principles, do not have to have punishments attached, there should at least be an ethical community which can at least register disapproval of the behavior.

However, realism is clearly not a workable theory for essentially globalized institutions. It is a theory of the relation between states, not globalized institutions. And we have already seen that globalized institutions impact the well-being of those who live in states. It remains to be seen, however, whether principles higher than self-interest can be formulated which govern these institutions, and whether there is an appropriate community which accepts them.

There is an interesting variant on realism. It holds that principles should not take priority over state power because societies have different ethical standards and those standards should be respected. But since there are principles which allow us to judge whether a society is just or manifestly unjust, there seems to be no reason to respect all standards in other societies just because they are different societies. 
The society of states position holds that there is an ethical community of states. Rawls, in his later work The Law of Peoples (1999b), develops a social contract view of international justice, which differs from the social contract for domestic justice. Principles of international justice are chosen, not by the political officials of each nation or nation state, but by peoples. On a social contract view, members of a given social group are the source of state and national authority, not the other way around (Rawls, 1999b, pp. 25-27). Rawls constructs a second social contract to govern relations between peoples. The principles chosen he calls the Law of Peoples. The basis for the second social contract is that the representatives of any society must be able to agree to principles without knowing how their society would be favored or disfavored by those principles. Many principles that Rawls claims would be chosen to regulate relations between societies are analogous to principles that would be chosen by individuals to regulate their own societies. First, they honor human rights, respect each others freedom, and respect cooperative agreements made between them. Second, peoples do not intervene in each others affairs and only make war in selfdefense. (These principles are parallel to the Greatest Equal Freedom Principle). Third, peoples have a duty to assist other people living under unfavorable conditions (Rawls, 1999b). (This principle is parallel to the Difference Principle.) The Law of Peoples, as Rawls formulates it, respects the integrity of individual societies. Not only is there to be no authority over all peoples; but the analogue of the Difference Principle, the duty to assist "burdened societies" (Rawls' term for people living under unfavorable conditions) is much more limited than the Difference Principle. One society is permitted to be a lot better off than another. The only duty is to help less fortunate societies to attain what is necessary to maintain a just democratic society. Justice between societies does not require redistribution to make the least well off society as well off as possible (Rawls, 1999b, sections 15 and 16). Rawls argues that the peoples' representatives will not choose to trade off economic benefits and burdens between peoples. Rawls says:

... no people organized by its government is prepared to count, as a first principle, the benefits for another people as outweighing the hardships imposed on itself. (Rawls, 1999b, p. 40)

In other words, although we can have agreements between societies (and parties within those societies) which redistribute benefits and burdens, we must first be assured that the internal arrangements within those societies are just. It doesn't count toward the justice of institutions in the U.S. to point to our good work in Afghanistan. And conversely, it doesn't ameliorate injustice in Afghanistan to point to our contribution to improving the lot of the least advantaged in the U.S. So the justice of transnational redistribution of benefits and burdens is necessarily a secondary matter, to be considered against a background of justly functioning institutions on the home front.

Cosmopolitans, whether utilitarian or contractarian, would strongly disagree. Peter Singer, in his One World (2004), argues that the basic unit for our ethical thinking must now be the entire planet. Problems such as global warming, environmental protection, economic development and redistribution, and genocide cannot be addressed on a state-by-state basis. Singer is explicitly a utilitarian and provides strong utilitarian grounds for a cosmopolitan approach to these problems. I believe that a social contract approach is probably better than a utilitarian approach, although utilitarianism gives good first-cut answers to many ethical problems. Utilitarianism is concerned with maximizing value, or maximizing average value. It doesn't care very much about how any specific individuals (especially the worst-off) make out, so long as the overall sum is better. Under utilitarian principles a loss in one society can be outweighed by a gain in another. So the losing society can end up, on its own terms, much worse off. An example is corn production in the U. S. and Mexico after NAFTA. Subsidized U.S. corn drove small Mexican corn producers out of business. Overall, economic benefits increased. But since we are separate societies, most such out-of-work Mexicans who come to the U.S. to raise corn now shipped to Mexico, often come as 
illegal aliens (Bensinger, 2003). I don't think any of our global ethical positions can deal with this kind of situation.

Another problem is that the institutions needed to implement a cosmopolitan ethical view are as yet very imperfect, and a social contract for globalized institutions does not exist. Singer concedes that the appropriate global institutions do not exist, but thinks current ones such as the United Nations are a good start (Singer, 2004). Merely extending Rawlsian domestic justice to the entire world does not take seriously the facts that there are separate societies and that global economic production is already largely in the hands of an institution not even mentioned in most works on globalized justice - the multinational corporation. This criticism also applies to Rawls' Law of Peoples. 'Corporation' does not even appear in the index.

\section{The Ethics of Ethically Global Institutions}

Corporations are legally individuals but not ethically individuals. Commentators as diverse as activist Michael Lerner and former Labor Secretary Robert Reich agree that corporations are not going to sacrifice profits for social goals (Reich, 2007). Lerner notes, "Even the corporate executives with the highest level of spiritual sensitivity . . . have no choice but to accept corporate profits as the absolute bottom line" (Lerner, 2000, p. 311). Corporations are concerned about their reputations because that can affect the bottom line. But this concern is a very limited and primitive form of ethics (Kohlberg, 1976). Corporations are not individuals with an ethical point of view. They cannot be regarded as parties to the social contract. So we have the spectacle of tobacco corporations contributing predictably to the deaths of millions over the years - and still staying profitably in business even after paying millions in lawsuits. Multinational corporations are also not bound by considerations of justice when they send jobs offshore.

Other commentators simply extend individual ethics to corporations. Thomas White (2007) asserts that the 'job' of business is to make life better for everyone in society. Michael Hopkins (2003) describes a "planetary bargain" in which corporations undertake to be socially responsible. Both of these commentators assume that we have a good idea of what globally ethical behavior would be for corporations and that corporations simply have to behave. More typical is the case of FedEx, which, though officially committed to minimizing greenhouse gases, has decided not to implement more than a token replacement of dirty trucks. The reason, says their environmental director Mitch Jackson, "We have a fiduciary duty to our stockholders." There are better uses of company capital (Elgin 2007).

The economist Joseph Stiglitz takes a much more judicious view. In his Making Globalization Work (2007, chap. 7) he notes myriad abuses of corporate power, very many of them involving corporations playing off one state against another: bribery or political contributions to overlook environmental regulations; monopolization accompanied by threats simply to pull out if the country tries to regulate them (Microsoft in South Korea); monopolistic price fixing. As he sees it, the problem is that the corporate goal of maximizing profits very often conflicts with social goals. Stiglitz makes a number of suggestions to improve matters, among them: allowing more legal transparency between countries when corporations act transnationally; a global competition law and a global authority to enforce it; enlarging liability of corporate officers when egregious violations of environmental protection laws occur; a common carbon tax.

Stiglitz's suggestions begin to address the issue raised by ethically globalized institutions, especially corporations. Solutions within a society and principles dealing with how societies relate to each other simply don't touch many of the problems. Some of his suggestions allow state sovereignty to be penetrated. Others require a global authority above states (competition laws, common carbon tax). 
Rawls and many other global ethics commentators are sure that a global authority is not a good idea. They follow Kant in thinking that a global state would either be a "despotism or riven with dissension" (Kant, 1795, Ak: VIII: 367). The problem is that having a sovereign with power over sovereigns is impossible. This is why Kant (and Rawls, following him) calls instead for a society of states. However, because of ethically globalized institutions, some problems are insoluble unless there is a global authority with power over institutions, at least in global economic matters, as for example with anticompetitive actions enabled in a global way.

Actually, the World Trade Organization and the World Bank are institutions of the right kind. The WTO would be in a position, for example, to insure that environmental laws were followed. But in fact, they adopt legalistic excuses making it impossible for various countries to enforce environmental protection laws (Singer, 2004, pp. 55-66). The WTO and World Bank would also be in a position to formulate policies regulating competition, bank secrecy, and (to return to our early examples) the use and regulation of IT amongst different states.

But on a contractarian view, any enforceable authority must rest on a contract agreed to by those under that authority. But before we can consider the nature of this contract for a global economic and political authority, we need to reexamine the role of corporations within a domestically just society. For many of the problems raised by multinational corporations are simply extensions of socially irresponsible behavior of corporations.

Corporations are unique because they are legally individuals - and must be to fulfill their legal function. But they are not subject to the ethical considerations of individuals. For other groups, such as governments and voluntary associations, ethical responsibility lies with the leaders of those organizations. And for governments, the principles of justice provide a whole extra level of ethical constraints. But for corporations, individual leaders are legally protected from being personally liable for the damages caused by their leadership. Therefore the solution has to be a new set of legal requirements for corporations which serve the function of providing ethical accountability.

Limited Partnerships and sole proprietorships can also behave unethically, but the problem of ethical responsibility is considerably more severe in the case of corporations

The first step is the minimal one of having corporations not act like sociopathic monsters: No killing people, no lying to cover up your mistakes, no thwarting the legitimate rights of your employees through union-busting, complying with accepted accounting standards for truthfulness in financial reporting. Even meeting these four requirements for a corporate ethical evaluation would be an enormous improvement in corporate behavior in the worst cases. Some further steps would be outside periodic ethical review by an authority with the power to dismantle the corporation and sell off its assets. In any case, corporations should be prohibited from attempting to influence public policy by advertising or campaign contributions or by financing electoral initiatives. In California, corporations routinely distort the initiative process by fielding several initiatives similar to the one they want to defeat, solely to confuse the public. Remember that corporations are only legal individuals. They do not inherit rights from nor should they be participants within a domestic social contract.

These suggested regulations on corporations (or quite likely others) are necessary within a domestically just society in order to preserve the justice of the society. We would expect analogues of them to be necessary to prevent multinational corporations from damaging or distorting global justice. 


\section{Another Social Contract}

On a contractarian view, any enforceable authority must rest on a contract agreed to by those under that authority. Multinational corporations will be under that authority. But they can't be parties to the contract because they are not ethical individuals. The parties must be individuals - but not representatives of societies, as in Rawls' Law of Peoples (1999b). We are not trying to establish another agreement between societies. But neither should we include all human beings on the basis of their humanity, as the cosmopolitans would have it for two reasons. (1) It is hardly an ethical requirement or a requirement of justice that all inhabitants of the planet take part in technologically intense Western Civilization. We want to allow indigenous peoples who don't want to become part of Western Civilization to do so. However difficult this may be, the possibility has to be allowed for. (2) A major function of a social contract is to allocate socially produced goods fairly. So the individual parties must be those benefiting from or contributing to globally produced benefits.

Therefore, the contract should be between parties involved in the multinational economy, representative of individuals contributing to or benefiting from a global economy. Corporations produce benefits for themselves, their stockholders, and other stakeholders such as societies and individuals. So the parties to the contract should be representatives of stockholders, of societies, and of individuals involved in the global economy. For the purposes of the agreement, they should not know whom they represent. This guarantees fairness in the same way as the domestic social contract. It seems clear to me that they will choose principles not on utilitarian grounds but rather on maximin grounds. (Maximin is choosing the alternative that will make you best off in the worst case.) Thus they have to adopt rules for corporations which will maximize the benefits of individuals participating in the global economy, but not rules which may cripple the productivity of corporations in such a way as to make everyone, even the worst-off person, still worse off. I believe they will also choose an analog of Rawls' greatest equal freedom principle, but with the caveat that corporations are not individuals, nor are states.

Here, then, is the beginning of the ethical answer to Yahoo! Shareholders certainly have equal rights, but they don't have the right to deny equal rights to participants in the global economy, or users of the enabling technology of the global economy. Thus they do not have the right to prevent Yahoo from enforcing equal rights.

Our other problem, the ethical status of the World Bank, would be handled by noting that ethically global institutions are bound by the principles of justice appropriate to the global economy. Thus they would have to adopt policies which tended to make those in the worst off societies as well off as possible. Demonstrably adopting policies of fiscally responsible international bankers is not the way to do this.

Although the position I have just developed is similar to cosmopolitanism, the important difference is that it is not administered through individuals but through the current institutions of globalism. Quite a bit more work needs to be done to establish that it is not, like cosmopolitanism, a purely utopian ethical position. I hope to have indicated the beginnings of an appropriate direction.

\section{Epilogue}

Problems of environmental ethics transcend global justice, I believe. We can be behaving fairly toward each other across the globe, but yet let the environment deteriorate in catastrophic ways. I believe principles of environmental ethics have to be treated as of higher order, and therefore of greater priority than even principles of global justice (Schultz, 2006, chaps. $12 \& 13$ ). But that is a topic for another occasion. 


\section{References}

Arendt, H. (1965). Eichmann in Jerusalem. New York: Viking Press.

Bensinger, K. (2003, September 9). Mexican corn comes a cropper. Washington Times, p. A1.

Center for Economic Justice. (2004). Investing in World Bank bonds: What are the risks? Retrieved December 3, 2007 from info@econjustice.net

Daniels, N. (2003). Reflective equilibrium. Stanford encyclopedia of philosophy. Retrieved January 31, 2008 from http://plato.stanford.edu/entries/reflective-equilibrium

Elias, P. (2007). Yahoo, jailed journalists, settle lawsuit. Retrieved November 13, 2007 from http://news.yahoo.com

Elgin, B. (2007, October 29). Little green lies. BusinessWeek, 45-52.

Hobbes, T. (1651). Leviathan. Retrieved June 20, 2007 from http://darkwing.uoregon.edu/ rbear/hobbes/leviathan.html

Hopkins, M. (2003). The planetary bargain. London: Earthscan Publications.

Kant, I. (1795). Perpetual peace. Translated in H. Reiss (Ed.), Kant's political writings, (1970). Cambridge: Cambridge University Press.

Kohlberg, L. (1976). Moral stages and moralization. In T. Lickona (Ed.), Moral development and behavior. New York: Holt, Rinehart \& Winston.

Lerner, M. (2000). Spirit matters. Charlottesville, VA: Hampton Roads.

Locke, J. (1690). The second treatise of government. Retrieved June 20, 2007 from http://www.constitution.org/j1/2ndtreat.htm

McFarlan, W., \& DeLacey, B. (2003). Enabling business strategy with IT at the World Bank. Harvard Business School Case No. 304-055.

Mill, J. S. (1863). Utilitarianism. Retrieved June 20, 2007 from

http://etext.library.adelaide.edu.au/m/mill/john_stuart/m645u/

Pogge, T. (2002). World poverty and human rights. Cambridge: Polity Press.

Rawls, J. (1999a). A theory of justice (revised ed.). Cambridge, MA: Harvard University Press.

Rawls, J. (1999b). The law of peoples. Cambridge, MA: Harvard University Press.

Reich, R. (2007, September 10). It's not business' business. Business Week, 86.

Rousseau, J-J. (1762). The social contract. Retrieved June 20, 2007 from http://www.constitution.org/jijr/socon_01.htm

Schultz, R. (2006). Contemporary issues in ethics and information technology. Hershey, PA: IRM Press.

Singer, P. (2004). One world (2nd ed.). New Haven, CT: Yale University Press.

Stiglitz, J. (2003). Globalization and its discontents. New York: W. W. Norton.

Stiglitz, J. (2007). Making globalization work (pp. 220-225). New York: W. W. Norton.

White, T. (2007). Data, dollars, and the unintentional subversion of human rights in the IT industry. Waltham, MA: Center for Business Ethics.

Yahoo's China Policy Rejected. (2007, June 12). BBC News. Retrieved December 2, 2007 from http://news.bbc.co.uk 


\section{Biography}

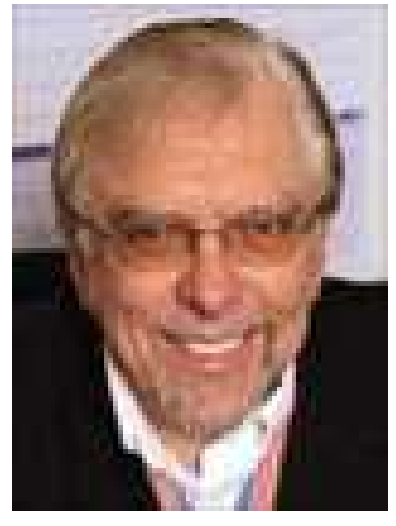

Robert A. Schultz received his Ph.D. in philosophy from Harvard University in 1971. His dissertation in ethics was under the direction of John Rawls. He was a member of the philosophy faculty at the University of Pittsburgh, Cornell University, and the University of Southern California, and taught courses and published articles and reviews in the fields of ethics, logic, and aesthetics. In 1980 he assumed the position of Data Processing Manager at A-Mark Precious Metals, a Forbes 500 company, then in Beverly Hills, CA. From 1989 through 2007 he was Professor of Computer Information Systems and Director of Academic Computing at Woodbury University, Burbank, CA. He has numerous publications and presentations in the areas of database design, I.T. education and ethics, and the philosophy of technology. His book, Contemporary Issues in Ethics and Information Technology was published in 2006. $\mathrm{He}$ is currently Professor Emeritus and Chair Emeritus of Information Technology at Woodbury University. 